\title{
Oldest mickwitziid brachiopod from the Terreneuvian of southern France
}

Lea Devaere, Lars Holmer, Sebastien Clausen, and Daniel Vachard Acta Palaeontologica Polonica 60 (3), 2015: 755-768 doi:http://dx.doi.org/10.4202/app.00021.2013

Kerberellus marcouensis Devaere, Holmer, and Clausen gen. et sp. nov., originally described as Dictyonina? sp., from the Terreneuvian of northern Montagne Noire (France) is reinterpreted as the oldest relative to or member of mickwitziid-like stem-group brachiopods. Were extracted 170 partial to complete phosphatic internal moulds of two types of adult and one type of juvenile disarticulated valves, rarely externally coated with phosphates, from the calcareous Heraultia Member of the Marcou Formation. They correspond to microbially infested, ventribiconvex, inequivalved, bivalved shells. The ventral interarea is bisected by a triangular sinus. The shell, most probably dominantly organic in origin, is orthogonally pierced throughout its entire thickness by radially-aligned, smooth-walled, cylindrical to hourglass shaped canals except for the sub-apical planar field (interarea). The through-going canals of $K$. marcouensis are compared with brachiopods endopunctae and with canals of mickwitziid brachiopods. The absence of striations on $K$. marcouensis canal walls, typical of mickwitziids, implies that (i) the tubes could have been depleted of setae or; (ii) traces of the microvilli were not preserved on the tube wall (taphonomic bias) or, (iii) the tubes could have been associated with an outer epithelial follicle.

Key words: Brachiopoda, Mickwitziidae, shell canals, Cambrian, Terreneuvian, West Gondwana, France.

Léa Devaere [lea devaere@hotmail.fr], Sébastien Clausen [sebastien.clausen@ univlille1.fr ], and Daniel Vachard [daniel.vachard@univ-lille1.fr], UMR 8217 Géosystèmes

CNRS-Université Lille 1, bâtiment SN5, avenue Paul Langevin, 59655

Villeneuve d'Ascq, France; Lars Holmer [Lars.Holmer@ pal.uu.se], Department of Earth Sciences, Palaeobiology, Uppsala University, Villavägen 16, SE-752 36 Uppsala, Sweden.

This is an open-access article distributed under the terms of the Creative Commons Attribution License (for details please see creativecommons.org), which permits unrestricted use, distribution, and reproduction in any medium, provided the original author and source are credited. 
FaFf Full text $(1,876.0 \mathrm{kB})$ 